Journal of Urban and Regional Analysis, vol. VII, 1, 2015, p. $83-100$

\title{
URBAN IDENTITY AND IRANIAN NEW TOWNS
}

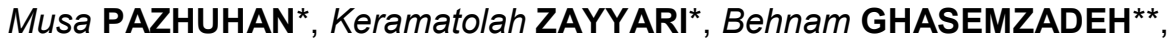 \\ Hamid QURBANI*** \\ * Tehran University, ${ }^{* *}$ Islamic Azad University, ${ }^{* * *}$ University of Science \\ and Culture, Tehran Urban Planning and Research Center, Iran
}

\begin{abstract}
In an era when urbanization on a large scale and at a rapid pace has become a dominant trend, particularly in developing countries, the fundamental issue of urban spaces identity is always being ignored. This is an important issue in two respects. First, it refers to the weakening of the identity elements over time, coinciding with the new development; second, it regards the lack of attention to identity stimulants, and failure in using them in a figurative and semantic manner in a small-scale structure to the macro-scale of urban tissues. The relative identity crisis is particularly apparent in new towns and it is one of the obstacles to attract population into these soulless towns. The main purpose of this paper is to evaluate the identity of 10 new towns in Iran to achieve a conceptual-cognitive framework for reviewing the above mentioned problem. We conducted this research based on qualitative and quantitative methods and by the use of the Goeller matrix and of a qualitative survey questionnaire. Findings indicate that in terms of selected measures, the new town of Baharestan achieved the first place and the other two towns "Andisheh and Pardis" occupied the next ranks. Results indicate that among new towns under investigation, the new town of Baharestan got the highest rank because its principles of identity were inspired by the principles of the Isfahan School.
\end{abstract}

Key Words: urban identity, new towns, the Isfahan Urbanism School, Goeller matrix, Iran

\section{Introduction}

New Urbanism and Smart Growth are relatively new approaches to urban design that deal with environmental problems, housing issues, and community well-being. Rapid pace of urbanization that affected the third world countries is a by-product of the post-1945 period. In most developing countries like Iran, the spatial population distribution is not balanced, leading to deficiencies in services, hygiene and the formation of slums. In order to balance these patterns across the country, different strategies have been applied, one of which being the construction of new towns (Zali et al. 2013). New towns have been built in most parts of the world during all periods of history since urbanization began (Ziari 2006). Socially, cities are places suitable for the formation of social institutions, promoting cultural values, expanding and strengthening social relationships, preserving human values as well as local and national identities. Therefore, the identity of the urban environment has become one of the most controversial issues in the present era (Negarestani et al. 2010).

Anonymity, homogeneity and heterogeneity, which are observed in many of the modern cities and are expanding at an increasing rate, have not only created an unfamiliar environment and unfavorable landscape for residents but they have also overshadowed all aspects of socioenvironmental life in urban communities, because the physical form of cities is in fact the kernel of the social world that affects all aspects of society from economics to aesthetics. Hence, one of the major problems by which large cities in general and the new towns in particular are plagued today is the urban identity and the lack thereof in their body and soul (Azizi and Arbab 2010, Moshiri et al. 2011). The results of such planning policies, after a few decades, are 
overpopulation, migration and accumulation of industries in or around these cities, including also the loss of their identity (Ferdowsian 2002).

Today, cities in Iran are being formed and expanded, not on the basis of their original identity, but based on the emulation of western trappings and modern patterns without considering their vernacular patterns (Rezvani 2005). Actually, the period of modernization should be considered as the beginning of rupture and ignorance in the urban identity and social life of urban spaces. As a result of fascination by exotic trappings, the indigenous cultural manifestations have been utterly ignored. On the one hand, due to the lack of knowledge and indifference towards the importance of indigenous patterns from this period onwards, realities were being ignored in the urban development projects. On the other hand, due to the increasing popularity of Western culture, which has surrounded the community by technological tools, causing massive influx of unfamiliar Western patterns, the today identity and its multiple dimensions are sought and brought from outside the country which is ingrained with the concept of "retrieved from external identity" (Naghizadeh 2013).

In the inevitable trend of globalization and the influence of countries with advanced civilization and development background, most of the countries with cultural-historical systems are concerned over their identity. They have realized that they should adapt their general development policies with the covert culture of the society, so that by promoting the noted policies they can deal with the unintended consequences of such a powerful influence. All the factors above have caused an obvious gap between urbanization, culture, thought, and history which is in turn the consequence of the historical rupture in the modern era. This rupture is more tangible in the new towns, where due to the absence of historical context, an important contributor to identity will be eliminated spontaneously, and other factors will inevitably be used to enhance identity.

The urban form in the Iranian cities is defined according to the meaning got by its identity format from the content that is affected by the theoretical foundations of the Iranian architecture, art, and urbanism, emphasizing that the form-content relationship like the body-spirit relationship is obvious in the worldview foundations. According to the historicalcultural necessities, there are three steps required to find future-oriented solutions to the identity problems in the new towns: first, recognizing the identity factors in the historical process of Iranian cities in line with the correct explanation of the issue; second, assessing the current situation and calculating the distance to the desired position; and third, finding strategic solutions to achieve identity in the development process of new towns. This study is an attempt associated with the first and second steps above to provide a conceptual-cognitive framework for reviewing this vital issue, as well as measures to promote urban identity. The main objective of this study is to evaluate the identity of 10 new towns in Iran (after the Islamic revolution) to achieve a conceptual-cognitive framework for reviewing the identity of urban spaces in the new towns.

\section{Methodology}

This research used the analytical method to measure the identity of the new towns in Iran (10 towns selected in this study, Fig. 1) using the Goeller matrix model methodology (Patton and Sawicki 1986) to evaluate the results of the relevant questionnaire. The Goeller matrix approach considers the impacts with the options in currency, natural, temporal or in physical units (such as towns and urban area). In this method, each matrix row represents an impact (which is measured based on an indicator) and each column represents an option. Various options are evaluated based on the selected indicators. Number, color or marking can be used to illustrate the results of the evaluating options. Thus using this method, the types of quantitative and qualitative impacts can be applied. This method is also flexible enough; so that it allows the decision maker to determine appropriately the weight for different indicators. 


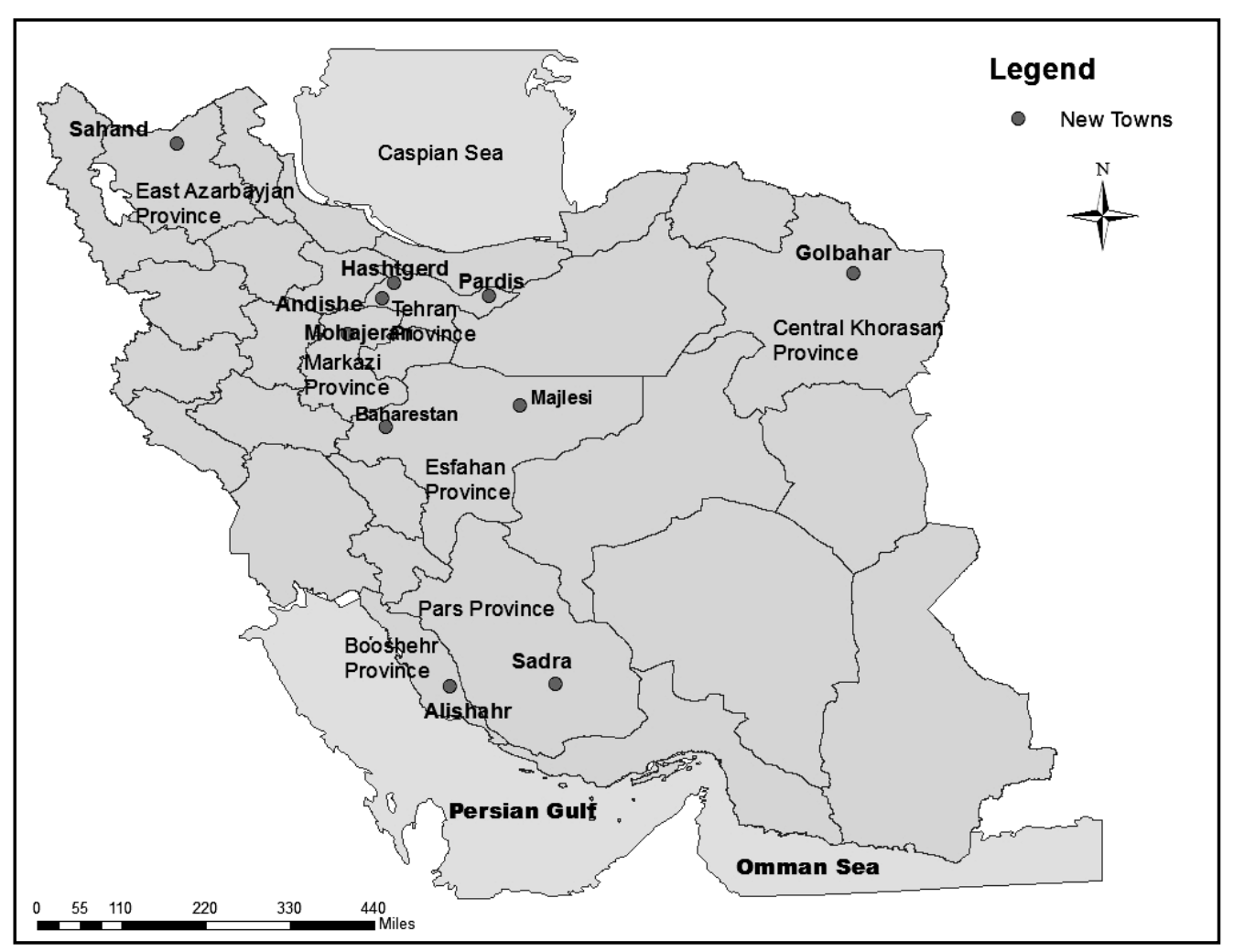

Fig. 1 - The location of the surveyed new towns in Iran

Due to flexibility, simple applicability and possibility of using an interval scale in this research (because of the spectral nature of the topic under assessment, namely identity), this evaluation method was used for weighting the rate of using the indicators of the Isfahan school of urbanism in the new towns. So for the assessment, the names of towns are listed in a matrix row and the names of the considered indicators are listed in a matrix column.

In order to apply this procedure, and due to the conceptual affinity (Ahari 2001, Ahari 2005, Habibi 2012, Habibi 1995a, Mahdavi 2010) to the indicators of urban identity on the one hand, and because of the good coverage between the identified indicators and the concept of sustainable urban design on the other hand, the identified indicators of urbanization inside the Isfahan School were used as documented indicators, according to which 50 questionnaires were distributed and completed separately among academic and professional experts in the 10 selected towns. In total, 42 questionnaires were finalized and analyzed. The questionnaire was written and completed in the period of one month of the late 2013. Its goal was the use of knowledgeable experts' views in order to rank the new towns according to the rate of their enjoyment from the Isfahan school of urbanism as a desired type of Iranian urbanism. 25 people were selected from the population of urbanism experts working in the new towns; so, the share of each city was of averagely 2.5 people. But this distribution was done based on the population of each city, so namely 3 people were selected from larger cities and 1 person was selected from small cities. The experts who completed the questionnaires were split in two groups: 25 people from the scholars of urban identity area and 25 people from the urbanism 
experts working in the construction companies of the new towns, which were aware of the identity issue and its related problems in the new towns. In Table 1, the considered indicators were presented for measuring the condition of identity in the new towns. The measurement was done based on these indicators.

Table 2 is the same as the questionnaire form. So that the indicators of the Isfahan urbanism school were listed in the column of the table and the names of the towns in the row; and then the respondents were asked, based on each indicator considered separately, to give to every city scores from $A$ to $E$. The range of scores was from 2 to 10 ; so according to Table 3 , the score $A$ has 3 points and the score E 10 points. Afterwards, according to the weighting that was done by the experts; based on Fig. 2, a general conclusion was done on the condition of weighting the indicators in all towns. In the last stage, the towns were ranked based on Table 4 and according to the weight that was given separately to each indicator in every city. A total of 42 questionnaires were finalized and tested. Thus, the concept of urban identity in Iran and the scientific literature was initially scrutinized and analyzed applying the intended indicators in the target towns based on the Goeller matrix. The results of the quantitative calculation were presented in the form of the final findings of the study, and then the final discussion and conclusions of the research were submitted.

\section{Scrutinizing the Target indicators to Measure Urban Identity}

As a key component of Iran's urban policy and planning, new town development has been scrutinized from various aspects such as design and architecture, geography, and sociology, with much of the literature concentrating on the substantive challenges of the development process (Zamani and Arefi 2013). Iran's rapidly growing urban population is concentrated in a few large cities. Using the new town strategy, the government of Iran plans to direct the future population growth and economic activities from large cities such as Tehran, Esfahan, Mashad, Shiraz and Tabriz to the new towns around them (Atash and Beheshtiha 1998).

Having a set of identity features is essential, considering particularly one with physical-space dimension that could provide the possibility to achieve the appropriate scales and standards for testing the urban identity of the Iranian new towns. In the same time, this set of identity features has to meet the needs of Iranian cities as well as being applied in new towns according to their specific conditions. On the other hand, the physical tissue and the urban spatial structure are major urban aspects that shape the urban identity, since the formation of the physical urban tissue is affected by the thoughts, ideas, beliefs, activities, and culture of the local community. Understanding this part of the city can lead to a greater recognition of social, economic, and cultural aspects. In fact, the physical tissue provides the possibility to visually recognize the urban identity, and that is why it is more significant than the other dimensions of identity (Azizi and Arbab 2010). In this regard, the Isfahan School urbanization indicators are known as a movement for the revival and reinventing of the ancient Iranian flux, with its most obvious verbal combination seen in spatial and physical collections, and they are considered as the basis of assessment and modelling of the urban spatial-physical identity. The indicators of the assessment practice are presented in Table 1.

\section{Analytical Concept of Urban Identity}

Urban identity, architectural identity and the urban images about them are sometimes formed by very different components in a long period inside the urban space. A city is a territorial phenomenon, evolved in the history, resulting from culture, and the spatial effects of human roles in the geographical environment. The worlds' first cities were founded when primitive societies benefited from the capacity of production, storage and added-value exchange; however, while their various forms of construction represent a response to the individual and collective needs of dwellers, they enjoy features that demonstrate different understandings of 
The indicators of the Assessment of Urbanization in Isfahan School

\begin{tabular}{|c|c|c|}
\hline Indicator & Description & References \\
\hline Unity & $\begin{array}{l}\text { Urban space should be homogenous and all } \\
\text { its elements combine with a general identity. }\end{array}$ & \multirow{8}{*}{$\begin{array}{c}\text { Habibi 1995b, } \\
\text { Habibi 2012, } \\
\text { Ahari 2001, } \\
\text { Ahari 2006, } \\
\text { Ahari 2005, } \\
\text { Foroutan 2009, } \\
\text { Mahdavi 2010, } \\
\text { Habibi and Habibi } 2010\end{array}$} \\
\hline Accumulation & $\begin{array}{l}\text { Its meaning is the gathering of various } \\
\text { elements of urban space in a certain place } \\
\text { which causes the creation of a special space } \\
\text { identity in that place. }\end{array}$ & \\
\hline Contrast & $\begin{array}{l}\text { Diversity in facing the elements of urban } \\
\text { space forms the contrast indicator while it } \\
\text { homogenizes them in a general identity. This } \\
\text { principle save urban spaces from assimilation } \\
\text { and loss of identity. }\end{array}$ & \\
\hline Connection & $\begin{array}{l}\text { When urban spaces are connected to each } \\
\text { other, they express a concept in a general } \\
\text { format. }\end{array}$ & \\
\hline Proportionality & $\begin{array}{l}\text { It pursues the ratios of sizes, objects and } \\
\text { buildings, of full and empty spaces and the } \\
\text { ratio of human presence inside the space; } \\
\text { this indicator seeks for beauty. }\end{array}$ & \\
\hline Continuity & $\begin{array}{l}\text { It includes the past, the present, and the } \\
\text { future; it happens in the present while it has } \\
\text { its head in the past and its legs in the future. }\end{array}$ & \\
\hline Territory & $\begin{array}{l}\text { Each element of the urban space from } \\
\text { housing, as the smallest element, to texture, } \\
\text { as the largest element, has its own privacy. } \\
\text { The stranger and the relatives are defined in } \\
\text { each of these privacies; and it is natural that } \\
\text { by the movement from microelements toward } \\
\text { macro-elements, privacy will be alleviated. In } \\
\text { other words, fewer people can enter to } \\
\text { personal privacy at home than to city privacy. }\end{array}$ & \\
\hline Establishment & $\begin{array}{l}\text { Establishing a building in a certain place will } \\
\text { feature a special characteristic and identity } \\
\text { that is lacking in other places. }\end{array}$ & \\
\hline
\end{tabular}

the diverse communities of the universe and of the natural creation. Therefore, biological complexes along with their very existence portray the culture of their creators. A culture with both material and immaterial aspects; so that instruments, tools for living, material goods, and their production methods can be considered as components of "the material culture" while customs, beliefs, arts and sciences, and social norms are considered as the components of the "non-material culture" or "spiritual culture" of urban communities. Thus, urban identity includes characteristics such as: historicity; locality; collective memory; a particular historical period; a context of general and specific social relations (Madanipour 1996, Negarestani et al. 2010); and sense of individual, family, group, tribal, local (urban, rural, and national]) belonging; cultural, social, economic, and political events; the rights and duties of citizens or their absence; technology level; inferior-superior relationships; class status; international relations; and national status. 
Urban identity is born, grown, and transformed through the interaction of the above elements as well as their contradictions and communalities, while it contains several positive and negative aspects. Many pundits equate urban identity with urban personality, and consider it an element to distinguish cities from each other, while in psychological theories anything that causes distinction is not defined as "identity", but "personality". Researchers suggest that the lack of attention to urban identity is the outcome of the standard approach in the design of spaces and buildings, the technology and materials used in constructions, and the excessive similarity between cities and urban spaces. They attribute their reasoning to the existence of traditional cities, each being different from the others and having an unique identity. In other words, their identity is the result of unique historical, cultural, social, and physical characteristics.

Urban identity is both objective and subjective. It is objective because there are a set of outer contours in cities such as architecture, constructions, and human services. The major part of urban identity is subjective which is associated with the imaginations created inside the human mind by the urban fabric and urban space. Urban identity depends heavily on the attitude towards urbanization. If urbanization is viewed as an issue in the cultural context, then cities may be considered as the physical manifestation of culture (Ghasemzadeh 2013). Different identities emerge due to the manifestation of certain cultures in each environment based on natural resources, ideology, and common value systems. Some experts presented a comprehensive definition of the urban identity and its variants to identify the root causes of the crisis in modern cities.

\section{Urban identity of the City}

The importance of the concept of identity stems from being part of the very essence of place (Casakin et al. 2015). Identity is a sphere that helps individuals to recall a place and distinguish it from other places; like the individuals, cities also need to have different characteristics or distinctions. Consequently, identity has become not only a term, but rather a comprehensive theme and concept in making new places and built environments (Cheshmehzangi 2015). Like the individuals, identity is created by a large number of definable characteristics or elements (Lynch 1960).

Relph (1976) defined the demand of place identity as a deep human need that exists for compatibility and to join significant places. If we choose to ignore this need, then the future can be held in an environment where places are not important. On the other hand, if we choose to respond to this need and to exceed placelessness (Relph 1976), then there is a potential for the development of an environment in which places are reflecting and facilitating the diversity of human experiences (Oktay 2002). There are several reasons for the attempts to strengthen identity inside urban communities, including political and ideological motives, the need for a sense of belonging, the reaction against change as an adverse phenomenon and the need for cultural adversity in a world where culture becomes increasingly identical (Karimian 2010).

Historical efforts were made to develop the environment and they can never be repeated or experienced; so that these legacies represent certain productions at certain times, as well as a set of forces and will powers. We can shape the environment in a way that it has a strong sense of place, which is deeply felt by the inhabitants through their: prominent identity; human vitality; strong symbolic messages that will stimulate memories and tendencies; and structures that will shape the experiences of the individuals in a hierarchy or in certain patterns.

From the perspective of identity, the new towns represent a typical policy and symbolic planning created by planners, which is entitled "the image of culture", as a physical introduction of the human elements, representing the functional patterns that constitute culture. The findings of Teo (1996) indicate that, from the inhabitants' perspective, one of the fundamental flaws of 
the new towns of Singapore is the lack of attention of urban planners to urban identity and its characteristics and physical-spatial manifestations (Teo 1996).

\section{Urban Identity in Iran}

The concept propounded that Iranian urban identity includes the characteristics and values of Iranian architecture and urbanism before the arrival of Islam to Iran. The period began with the sedentary tribal lineages and tribes, their unity and the building of old towns. "The Temple City", the first of its kind, was built as a ziggurat at Chogha Zanbil about three thousand years ago. "The Government City", later on, was formed during the Median period in Ecbatana, and it eventually culminated at Persepolis. The urban tissue comprised a citadel, residential neighborhoods, warehouses, temples, gates, and fences (Mojtahedzadeh 2003). Later, along with the growth and prosperity of trade and economy, another important element, namely the bazaar, was placed in the heart of the city.

In general, what is noteworthy as a symbol of urban identity (at least from the physical spatial dimensions point of view), before the arrival of Islam in Persia (Sassanian period), is represented by the five key elements of the urban structure, which is formed during thousands of years in harmony with the climatic, economic, and social conditions, and along with the advancements made by the people in the fields of knowledge and material tools, each including particular elements such as temples, baths, and markets. The five elements are: Kohandej, medial shar (city), external shar, market, and square (Habib et al. 2008).

The identity, physical and spatial characteristics of the Iranian city were highly correlated and interdependent, so that not only they were not dissipated after the arrival of the Islam to Iran. Instead, they were combined with the Islamic world while the replacement of traditional elements with new ones, such as building mosques instead of temples, led to the formation of a new identity with a particular physical space, namely the Iranian identity. The three elements of the market, citadel, and Jame Mosque and their surrounding neighbourhoods, and other spaces such as cistern, or school and Tekieh, which were built sometime later, formed the elements and spaces of the ancient Islamic cities in Iran. In the Islamic period, the religious role of the city was more prominent and it outweighed by far its military and economic role.

In the period after the arrival of the Islam to Iran, the three physical elements of mosque, market, and neighborhood formed the characteristics of the Islamic city (Habibi 2012). In the context of its historical evolution and with all its ups and downs, consistent with the climate, economic, and social conditions and along with the advancement in knowledge and indigenous technology, the Iranian city created and completed its own physical spatial identity, and it presented a particular style of architecture and urbanism. The final stage of this historical trend was the Qajar era that coincided with the beginning of inequitable relations with the West. Also, an unplanned blindly imitation of the modernist culture in all aspects of economic and social life as well as inside the city represented the beginning for the elimination of the historical identity of the city, resulting in the mere imitation of foreign patterns without adaptation to the local conditions. Nevertheless, by the mid-sixties, with the promotion of comprehensive urban plans in different cities of Iran during the urban renewal process, traces of vernacular architecture and urbanism in buildings and structures were still visible. However, due to the popularity of comprehensive detailed plans, which were copied from the Western versions, particularly during the decades after the 1960s, those characteristics were forgotten and replaced by identical land use patterns in all cities.

What is noteworthy about the identity of the new towns in general, and the new towns in Iran, in particular (Ziari 2006), is that due to their newness, the issue of identity in these cities is different from the ancient cities with historical roots. The identity of citizens in old cities can be strengthened through the physical and visual reinforcement of valuable historical elements 
(Karimian 2010) as well as the emphasis of using them in urban design and planning. However, due to the lack of such elements in new towns, the issue of identity is somehow problematic. Because of the absence of history, culture, and collective memory derived from space, new towns will remain deprived of identity for a long time. They will not experience the formation of identity elements such as collective memory, unless they move toward becoming conventional cities. It is noteworthy that the population moving from other places to these new towns has its own history, culture, and collective memory that can facilitate the process of identification, provided that they are considered conscious urban inhabitants.

\section{Results}

As mentioned before, due to the positive characteristics of the Goeller matrix in the evaluation of multiple options based on different indicators, it was used to evaluate the urban identity of the new towns of Iran. The effects of the above mentioned options on the physical, natural, monetary and time units are considered inside the Goeller matrix methods. The indicators and options, as the method of the listed indicators specifies, are displayed in rows and columns, respectively (Table 2). Each row of the matrix represents an effect, and each column represents an option. The different options will be evaluated according to the chosen indicators. Therefore, the variety of the qualitative and quantitative effects could be applied by the Goeller matrix. The matrix allows the decision makers to determine a suitable weight for the different indicators. In this study, each of the sample towns is considered an option, and it is sorted in the columns of the matrix. The evaluation indicators are also demonstrated in the rows of the matrix as a system for the assessment of the options (new towns). The weighting algorithm and the resultant calculation of the questionnaires obtained from the 42 experts are shown separately for each criterion.

Goeller matrix for each of the indicators and

Table 2 the target towns in a network of intersecting cells

\begin{tabular}{|c|c|c|c|c|c|c|c|c|}
\hline \multicolumn{7}{|c|}{ INDICATOR } & New Towns \\
\cline { 1 - 7 } Unity & $\begin{array}{l}\text { Accu- } \\
\text { mulation }\end{array}$ & $\begin{array}{l}\text { Con- } \\
\text { trast }\end{array}$ & $\begin{array}{l}\text { Connec- } \\
\text { tion }\end{array}$ & $\begin{array}{l}\text { Propor- } \\
\text { tionality }\end{array}$ & $\begin{array}{l}\text { Conti- } \\
\text { nuity }\end{array}$ & $\begin{array}{l}\text { Terri- } \\
\text { tory }\end{array}$ & $\begin{array}{l}\text { Establish- } \\
\text { ment }\end{array}$ & \\
\hline C & D & B & C & D & B & B & C & Hashtgerd \\
\hline C & E & B & C & C & C & B & C & Pardis \\
\hline D & D & B & D & C & D & B & B & Andisheh \\
\hline B & B & C & B & C & C & C & C & Majlesi \\
\hline D & D & C & D & D & E & C & D & Baharestan \\
\hline B & C & B & C & B & B & C & B & Sahand \\
\hline B & A & A & B & B & B & C & B & Sadra \\
\hline C & B & C & B & C & B & C & B & Golbahar \\
\hline B & B & B & C & B & C & C & B & Alishahr \\
\hline C & C & B & C & C & C & B & C & Mohajeran \\
\hline
\end{tabular}

Source: Adjustment based on the researchers' analysis

The rows of the matrix above, adjusted in the form of different intersecting cells, evidence the indicators concerning the process of evaluation and the assessment of urban identity in the new towns of Iran; and the columns of the matrix display the names of the towns in which the above indicators are tested. The coefficients of each criterion were allocated to the target towns, and the weighing process was conducted based on the 5-fold scope and the points of $A$ to $\mathrm{E}$. To prioritize the intended indicators in the target towns, the weight of measures was 
determined separately in each new town according to the strength or weakness of the indicators in the distance scales. For example, Point B indicates the inappropriateness of the indicators in the target towns, and the quantitative equivalent to the range of the above matrix 4 of 10 . In other words, it can be assumed that the following equation was considered (Table 3):

Table 3

The output indicators for the calculation of Goeller matrix

\begin{tabular}{|c|c|c|c|c|c|}
\hline \multirow{2}{*}{$\begin{array}{c}\text { Sign } \\
\text { Distinction }\end{array}$} & A & B & C & D & E \\
\cline { 2 - 6 } & Very poor & Poor & Fair & Good & Very good \\
\hline
\end{tabular}

Given the equation above, the initial matrix is adjusted for the Goeller matrix. To obtain the final score of all indicators, it is necessary to apply the quantitative calculation procedure to each of the indicators in the new towns. Fig. 2 shows the results of the calculation for each indicator individually.

\begin{tabular}{|c|c|c|c|c|c|c|c|c|}
\hline Indicator & Distinction (\%) & & & & & & & \\
\hline Unity & 56 & & & & & & & \\
\hline Accumulation & & 60 & & & & & & \\
\hline Contrast & & & 44 & & & & & \\
\hline Connection & & & & 58 & & & & \\
\hline Proportionality & & & & & 58 & & & \\
\hline Continuity & & & & & & 58 & & \\
\hline Territory & & & & & & & 52 & \\
\hline Establishment & & & & & & & & 52 \\
\hline
\end{tabular}

Fig. 2 - The results of the Goeller matrix calculation for each measurement criterion Source: Adjustment based on researchers' analysis

According to the above table, some of the indicators proposed for the assessment of urban identity in the new towns were in a fair status while others were in a poor situation. In other words, indicators such as contrast and accumulation had a fair condition. In this regard, indicators such as unity, connection, proportionality, continuity, territory, and establishment were in a poor condition.

Table 4 shows the performance of the indicators intended for the target towns, on a distance scale. The desired scope in the corresponding graphs based on the 5 -fold scope ranged from 2 to 10 . Numbers 2, 4, 6, 8, and 10 indicate very poor, poor, fair, good, and very good conditions, respectively. Whereas any indicator has usually a quite good or a quite bad performance in the planning system, therefore the result of the final assessment of this study ranged between these two variables. The results of all calculations of the indicators used in this study ranged from poor to good are individually shown in the following diagram (Fig. 3). 


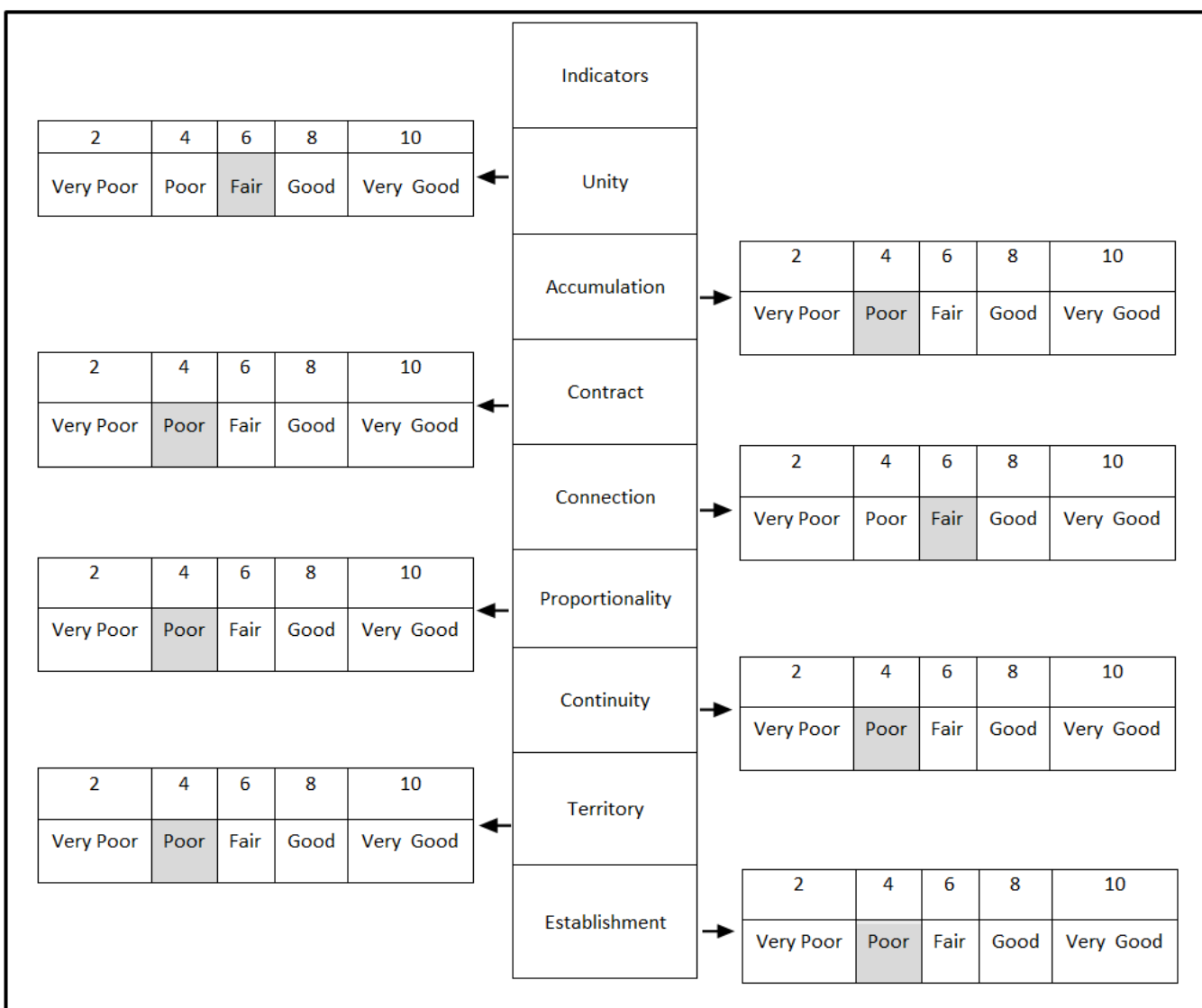

Fig. 3 - Findings from the calculation of research indicators based on interval scale Source: Adjustment based on researchers' analysis

Thus, according to the distance scale, the final rating of all new towns under study is obtained through the incorporation of the 8 indicators (Table 4).

Table 4

Final ranking of new towns based on the identification of indicators of the Isfahan school of urbanism

\begin{tabular}{|r|l|r|r|l|r|}
\hline Rank & \multicolumn{1}{|c|}{ City } & Final score & Rank & City & Final score \\
\hline 1 & Baharestan & 62 & 6 & Majlesi & 42 \\
\hline 2 & Andisheh & 50 & 7 & Golbahar & 40 \\
\hline 3 & Pardis & 48 & 8 & Alishahr & 38 \\
\hline 4 & Hashtgerd & 46 & 9 & Sahand & 38 \\
\hline 5 & Mohajeran & 44 & 10 & Sadra & 30 \\
\hline
\end{tabular}

Source: Adjustment based on researchers' analysis 
As illustrated in the above table, Baharestan new town had a rating of 62 , being the first among the ranked towns, while Andisheh and Pardis held the 2nd and 3nd positions, respectively. Interestingly, the results of this study are consistent with the high population of these cities, indicating the effectiveness of the above indicators on high population in the target towns.

According to the results of the evaluation in the new towns and in order to promote urban identity in the new selected towns, there is a framework presented in Table 5 which may help planners and managers in the decision making process in new towns. In this table, due to the situation set based on the Goeller matrix, two current and optimal situations were surveyed for each index. In surveying the current situation, each index of the Isfahan urbanism school was studied and described for all the new towns. Then, in order to improve the identity situation of the new towns, some recommendations were given based on the conditions of each indicator. In these recommendations, a set of strategies has been proposed including the creation of a neighbourhood centre, following the indicators of the new urbanism movement - pedestrianoriented; variety performances; lively urban spaces - creating the perspective of the Iranian identity. This strategy has been formulated with the aim of strengthening the identification that derived from the Iranian urbanism identity.

The unity indicator was used as a principle and its results show an improper situation in the surveyed towns. In the recommendations it is tried to improve this indicator by the use of physical unity strategies and by identifying the adequate materials for the facings of the new towns. In regard to the indicator of accumulation and due to its relative optimal situation, the creation of a neighbourhood centre and of different social interaction spaces was recommended. The contrast indicator has also a relative proper situation; so, in these towns, the integration of public spaces with values promoted by the new indicators of urbanism was recommended. The connectivity indicator including the connected urban spaces that express a physical concept in a general format had an improper situation in the surveyed cities. So, the physical framework amendment and the placement of different and appropriate performances were recommended to amend this situation. The proportionality indicator has also a situation similar to the connectivity indicator in the new towns; the amendment of the cityscape criteria, on the one side, and applying the sustainable management of land for the establishment of an appropriate application for a harmonious and sustainable development, on the other side, can lead to the improvement of its situation in the new towns. The continuity indicator as a principle that represents the concept of physical continuity of the urban spaces inside the Iran school of urbanism has an improper situation in the surveyed towns. Therefore, the creation of mixed land uses and the attempt to implement urban development projects were recommended to improve this situation. The territory indicator, which has been completely destroyed in the new towns by the dominance of the modernist urbanism, has also an improper situation; for the improvement of this principle, the pedestrian-oriented development, respecting private and semi-private spaces in the city, and including the suggested strategies were recommended. Finally, the establishment territory indicator, which unfortunately has also an improper situation, can be improved by the complete implementation of urban development projects, preventing land use changing and considering the harmony of form, space and activity indicators inside urban spaces. 
Presenting the Framework to Promote Urban Identity in the Selected New Towns

\begin{tabular}{|c|c|c|c|}
\hline INDICATOR & Assessment & $\begin{array}{l}\text { Results of the } \\
\text { Goeller matrix }\end{array}$ & Optimal State Necessities \\
\hline Unity & $\begin{array}{l}\text { According to the results of the } \\
\text { sample studies, no homoge- } \\
\text { neous system is formed yet in } \\
\text { terms of a unique identity } \\
\text { formation in the new towns. } \\
\text { Failure to establish dominant } \\
\text { urban spaces inside the urban } \\
\text { tissue, and lack of uniformity } \\
\text { in the formation of spaces } \\
\text { have caused irreparable } \\
\text { harms to the spatial harmony } \\
\text { and the relevant activities, } \\
\text { while they have disjoined the } \\
\text { physical system of the towns. }\end{array}$ & Poor & $\begin{array}{l}\text { In line with creating spatial unity } \\
\text { in both procedural and substan- } \\
\text { tive areas in the new towns, } \\
\text { measures should be taken for the } \\
\text { identification of public and private } \\
\text { physical spaces of the cities as } \\
\text { well as the formation of unity } \\
\text { indicators to evoke a whole unit. } \\
\text { Accordingly, the unit components } \\
\text { represent a particular gradation; } \\
\text { in the meantime, they lead to the } \\
\text { formation of a general homoge- } \\
\text { neous space. }\end{array}$ \\
\hline Accumulation & $\begin{array}{l}\text { Accumulation of different } \\
\text { urban spaces in a specific } \\
\text { range and a certain area } \\
\text { leads to increased vitality and } \\
\text { strong urban life in the new } \\
\text { towns. However, according to } \\
\text { the studies conducted on the } \\
\text { ten new target towns, there is } \\
\text { no evidence on the accuracy } \\
\text { of the above statement, with } \\
\text { the exception of certain areas } \\
\text { that have gained fair points } \\
\text { due to the increasing density } \\
\text { and formation of commercial } \\
\text { spaces. }\end{array}$ & Fair & $\begin{array}{l}\text { Accumulated activities and } \\
\text { spaces in a certain area of the } \\
\text { new towns bring identity and a } \\
\text { sense of presence of public spac- } \\
\text { es in the mind of the observer; } \\
\text { and due to its mixed use, and } \\
\text { despite its heterogeneity, public } \\
\text { space plays certain roles to the } \\
\text { people, and thus, it contributes to } \\
\text { their presence in these spaces. } \\
\text { To achieve such a position in the } \\
\text { new towns, attempts should be } \\
\text { made to strengthen the uniformity } \\
\text { of residential areas by creating } \\
\text { neighbourhood centres that enjoy } \\
\text { the accumulation of physical and } \\
\text { activity spaces. }\end{array}$ \\
\hline Contrast & $\begin{array}{l}\text { Due to the methods used and } \\
\text { the high scores, this indicator } \\
\text { is ranked fair among other } \\
\text { indicators. The issue was } \\
\text { discussed due to the variance } \\
\text { of residential units and } \\
\text { different densities in certain } \\
\text { areas, as well as the common } \\
\text { uses in different phases of the } \\
\text { new towns. The scope of this } \\
\text { indicator in the formation of } \\
\text { identity in the new towns has } \\
\text { gone beyond these indicators, } \\
\text { and it refers to the urban } \\
\text { spaces that in addition to } \\
\text { creating heterogeneity in } \\
\text { physical spaces are of a great } \\
\text { help in strengthening } \\
\text { functional relationships and } \\
\text { space consolidation, despite } \\
\text { the existing differences. }\end{array}$ & Fair & $\begin{array}{l}\text { In the new towns, the most } \\
\text { considerable indicators of } \\
\text { identification and creation of } \\
\text { urban living spaces are the ones } \\
\text { that lead to the formation of a } \\
\text { special system in a certain town } \\
\text { which is different from other } \\
\text { similar towns; and accordingly, } \\
\text { the city is distinguished from } \\
\text { other towns and it has its own } \\
\text { identity. In line with creating new } \\
\text { spaces in the contemporary } \\
\text { urbanism, this issue can comply } \\
\text { with some visual proportions of } \\
\text { Iranian traditional urbanism due } \\
\text { to the position of elements and } \\
\text { some certain spaces. In other } \\
\text { words, by combining the urban } \\
\text { elements of the new urbanism } \\
\text { movement and by creating } \\
\text { accessible urban public spaces, } \\
\text { we can attach more weight to the } \\
\text { indicator of contrast in the new } \\
\text { towns. }\end{array}$ \\
\hline
\end{tabular}




\begin{tabular}{|c|c|c|c|}
\hline INDICATOR & Assessment & $\begin{array}{l}\text { Results of the } \\
\text { Goeller matrix }\end{array}$ & Optimal State Necessities \\
\hline Connection & $\begin{array}{l}\text { Due to its unique nature and } \\
\text { in terms of the two aspects } \\
\text { below, this indicator was } \\
\text { ranked poor in the new towns } \\
\text { under study. On the one } \\
\text { hand, because of the new- } \\
\text { ness of new towns; the } \\
\text { physical rupture was evident } \\
\text { in their urban spaces. On the } \\
\text { other hand, since urban } \\
\text { spaces are not completely } \\
\text { formed, the indicator of con- } \\
\text { nection and the coverage of } \\
\text { physical spaces are not yet } \\
\text { occurred. In other words, in } \\
\text { addition to being interpreted } \\
\text { as spatial connection, it can } \\
\text { be defined as functional con- } \\
\text { nection in which each urban } \\
\text { space is similar to a mosaic } \\
\text { which has its special services } \\
\text { within its area, and together } \\
\text { with other functional spaces } \\
\text { can lead to the dynamism of } \\
\text { urban spaces. }\end{array}$ & Poor & $\begin{array}{l}\text { To achieve the desired position } \\
\text { in relation to the indicator of } \\
\text { connection, it is necessary to } \\
\text { modify the two corresponding } \\
\text { procedures since they are } \\
\text { imposing certain problems in the } \\
\text { present situation. In other } \\
\text { words, measures should be } \\
\text { taken to contribute to the } \\
\text { formation of a simultaneous and } \\
\text { harmonious physical develop- } \\
\text { ment by simply preparing the } \\
\text { suitable skeleton for the } \\
\text { formation of urban life in the } \\
\text { development phase. On the } \\
\text { other hand, by the application } \\
\text { and locating different functions } \\
\text { in the corresponding phases, it } \\
\text { will be able to connect spaces } \\
\text { and activities beyond physical } \\
\text { spaces. The above procedures } \\
\text { will bring about place sustaina- } \\
\text { bility freeing new towns from } \\
\text { uniformity of spaces provided } \\
\text { that they are taken into close } \\
\text { consideration. }\end{array}$ \\
\hline Proportionality & $\begin{array}{l}\text { It applies in two aspects of } \\
\text { structure and content in the } \\
\text { target towns, and it deals with } \\
\text { fundamental issues. So that, } \\
\text { this is due to the absence of } \\
\text { proportion between dimen- } \\
\text { sions and sizes, volumes and } \\
\text { buildings, and the ratio } \\
\text { between accumulated and } \\
\text { empty spaces; also, the lack } \\
\text { of congruent concepts in cer- } \\
\text { tain phases of development, } \\
\text { which are being separated } \\
\text { disproportionately, like is- } \\
\text { lands, causing spatial schism, } \\
\text { has undermined the indicator } \\
\text { of proportionality in the target } \\
\text { towns. }\end{array}$ & Poor & $\begin{array}{l}\text { Compatibility and conformity of } \\
\text { physical spaces, especially in } \\
\text { terms of their architectural char- } \\
\text { acter are the factors that should } \\
\text { be taken into close considera- } \\
\text { tion in order to fit and promote } \\
\text { the status of new towns accord- } \\
\text { ing to their development phases, } \\
\text { and due to the management of } \\
\text { space development. Establish- } \\
\text { ing specific design indicators for } \\
\text { facades and physical proximity } \\
\text { as well as equilibrating the } \\
\text { effects of surfaces, such as } \\
\text { streets and green spaces with } \\
\text { physical symptoms, can play an } \\
\text { important role in this regard. In } \\
\text { other words, the proportion of } \\
\text { development or land manage- } \\
\text { ment will attribute to establish } \\
\text { the procedures to fit the harmo- } \\
\text { nious development and expan- } \\
\text { sion of the new town; mean- } \\
\text { while, it will diminish the creation } \\
\text { of eyesore lands with less } \\
\text { developing capabilities. }\end{array}$ \\
\hline
\end{tabular}




\begin{tabular}{|c|c|c|c|}
\hline INDICATOR & Assessment & $\begin{array}{l}\text { Results of the } \\
\text { Goeller matrix }\end{array}$ & Optimal State Necessities \\
\hline Continuity & $\begin{array}{l}\text { The indicator of continuity } \\
\text { regains its meaning through } \\
\text { its relationship with disconti- } \\
\text { nuity. In other words, the indi- } \\
\text { cator of discontinuity in the } \\
\text { target towns is more apparent } \\
\text { than the indicator of continui- } \\
\text { ty. This is due to the lack of } \\
\text { strong physical contexts and } \\
\text { their repetition in the public } \\
\text { and private areas, and the } \\
\text { absence of uniformity in the } \\
\text { urban development of the new } \\
\text { urban centres; this issue is } \\
\text { about the phases that have } \\
\text { not yet been able to attract } \\
\text { public participation in the field } \\
\text { of constructions. That is, the } \\
\text { weakness of new urban cen- } \\
\text { tres is due to the lack of activi- } \\
\text { ty corridors corresponding to } \\
\text { the transference of a dynamic } \\
\text { urban space to the various } \\
\text { phases of development. }\end{array}$ & Poor & $\begin{array}{l}\text { In line with establishing uniformity } \\
\text { and empowering the important } \\
\text { indicator of continuity, as one of } \\
\text { the fundamental indicators of } \\
\text { identity and place vitality and as } \\
\text { an indicator that most of the con- } \\
\text { temporary new towns need to } \\
\text { strengthen, it is necessary to pay } \\
\text { close attention to the two issues } \\
\text { of form and activity. So that, due } \\
\text { to the physical rupture of urban } \\
\text { spaces, and by creating fields of } \\
\text { realization and evaluation, before } \\
\text { and during its implementation, we } \\
\text { can contribute to an optimal and } \\
\text { structured development. On the } \\
\text { other hand, improvement can be } \\
\text { achieved by creating mixed-use } \\
\text { areas, and by investments in } \\
\text { public spaces for linking all spac- } \\
\text { es of development through corri- } \\
\text { dors, while giving rise to urban } \\
\text { survival and public participation. }\end{array}$ \\
\hline Territory & $\begin{array}{l}\text { The main reason of the weak- } \\
\text { ness of the territorial indicator } \\
\text { in the target towns is repre- } \\
\text { sented by the modernist char- } \\
\text { acteristics of development } \\
\text { spaces, like in other Iranian } \\
\text { cities that increase their realm } \\
\text { horizontally in the form of } \\
\text { unbridled expansion of very } \\
\text { small buildings and passages. } \\
\text { This indicator has been ne- } \\
\text { glected in all the Iranian cities, } \\
\text { especially in the new target } \\
\text { towns, from two aspects. The } \\
\text { first aspect is territorial by } \\
\text { nature, which refers to failure } \\
\text { in applying particular spaces } \\
\text { and providing special territory } \\
\text { for them. The lack of urban } \\
\text { public spaces with a proper } \\
\text { covering radius for references } \\
\text { is an evidence for this matter. } \\
\text { The second aspect is called } \\
\text { special territory or private } \\
\text { territory. It is also due to lack } \\
\text { of privacy from the scale of } \\
\text { single buildings to their neigh- } \\
\text { bourhoods in the new the } \\
\text { towns. }\end{array}$ & Poor & $\begin{array}{l}\text { It will be possible to strengthen } \\
\text { this indicator according to the two } \\
\text { aspects of territorial by nature } \\
\text { and special/private territory. Ter- } \\
\text { ritorial by nature refers to the lack } \\
\text { of lively public spaces in terms of } \\
\text { their nature; and in case of exist- } \\
\text { ence they will have their own } \\
\text { special territory and a good cov- } \\
\text { erage over the new towns. These } \\
\text { public spaces can include the } \\
\text { entire urban space. The expan- } \\
\text { sion of private spaces with differ- } \\
\text { ent territories can also be the } \\
\text { most important aspect of the } \\
\text { expansion of the territorial indica- } \\
\text { tor in the realm of new towns. By } \\
\text { establishing limitations on road- } \\
\text { ways, this territory will take place } \\
\text { and will be greatly accepted by } \\
\text { the public in certain neighbour- } \\
\text { hoods or applications forming a } \\
\text { series. For instance, by creating } \\
\text { commercial applications in cer- } \\
\text { tain areas next to recreational } \\
\text { spaces, on the scale of a single } \\
\text { neighbourhood and roadway } \\
\text { access restriction to this unit; we } \\
\text { can help enhancing the territory } \\
\text { and to increase its property val- } \\
\text { ues, while also increasing the } \\
\text { private sector participation. }\end{array}$ \\
\hline
\end{tabular}




\begin{tabular}{|c|l|c|l|}
\hline INDICATOR & \multicolumn{1}{|c|}{ Assessment } & $\begin{array}{l}\text { Results of the } \\
\text { Goeller matrix }\end{array}$ & Optimal State Necessities \\
\hline \multirow{6}{*}{ Establishment } & $\begin{array}{l}\text { The establishment indicator } \\
\text { could be searched in the } \\
\text { combination of the previously } \\
\text { mentioned indicators, because } \\
\text { the establishment of a structure } \\
\text { in a specific location or urban } \\
\text { space should comply with the } \\
\text { guidelines and indicators } \\
\text { outlined earlier. If the } \\
\text { corresponding indicators are } \\
\text { applied, we can witness the } \\
\text { objectivity of the establishment } \\
\text { indicator. Due to the poor rating } \\
\text { of this indicator, there were } \\
\text { also fundamental weaknesses } \\
\text { in ten new towns surveyed in } \\
\text { this study. }\end{array}$ & $\begin{array}{l}\text { Poor } \\
\text { by the concepts of urbaniza- } \\
\text { tion and urban spaces so that } \\
\text { each component can play a } \\
\text { great role in the entire unit; } \\
\text { therefore, along with the } \\
\text { realization of indicators such } \\
\text { as territory, continuity, and } \\
\text { unity, the unique nature of } \\
\text { each space and the physical } \\
\text { and functional platform of the } \\
\text { space should also be } \\
\text { considered. In this case, the } \\
\text { three elements of form, } \\
\text { space, and urban life, in line } \\
\text { with each other, will lead to } \\
\text { the crystallization of urban life } \\
\text { and urban spaces. }\end{array}$ \\
\hline
\end{tabular}

Source: Adjustments based on the researchers' analysis

\section{Conclusion}

Unfortunately, even after almost 40 years of urban planning experience and a paradigm shift, planning for people, and not planning with people, is still prevalent in Iran (Zebardast 2005). The issue of identity is the main focus in the planned communities of the contemporary era due to rapid urbanization. The population which is going to live in these planned settlements has its own culture, history, and ancestral tradition; and this is of a particular importance in Iran. Urban identity today is as a missing link; and the cities are being formed and spread not on the basis of their original identity, but based on imitation of Western manifestations and modern patterns, without thought and regardless of the indigenous patterns. In fact, modernization is the beginning of the rupture and waning of interest in urban identity and social life. Fascination with the exotic manifestations has resulted in forgetting the traditional indigenous manifestations. Due to the lack of familiarity and ignoring the need for indigenous patterns, from this period onwards, territorial realities were being ignored in the urban development plans. Identity is an important issue in the new towns, and there is a direct relationship between identity and the high population of the new towns; so that towns that did not take this important issue into account have less population. According to researchers and experts, and based on the research direction as well as the results of the Goeller matrix, Baharestan new town achieved the highest ranking, on the basis of the selection of indicators extracted from the Isfahan school of urban development. In other words, the city's planning and design is more compatible with the indicators of identity inspired by the indicators of the Isfahan School. The city's success in achieving its goals among the Iranian new towns verifies the accuracy of what was stated above. One of the main objectives of this study is to present the standards and frameworks for the promotion of urban identity in the selected towns. Therefore, a one-to-one correspondence was used in the qualitative analysis of the results of the Goeller matrix calculations, according to which some indicators were proposed for reaching an optimal image of the 8 indicators mentioned above. It should be indicated that the methodology developed in this paper was associated with the other aspects of identity and its application in other towns. Finding practical solutions for the realization of the fundamental issue of identity in the modern new towns can represent the subject of future studies in this area. The results show that many indicators register a poor situation in the case studies considered and these results represent deep challenges for the new towns, where they constitute a great opportunity for the establishment of the Isfahan school of urban development as pick point of urban development approaches in an 
ancient country. Therefore, researchers have proposed the body of strategies for the promotion of indicators of this school in the new towns. Based on the situation of each indicator in each of the case studies, some strategies have been proposed. These strategies focused on the promotion of urban identities based on the local values of urban development especially inside the Isfahan school of urban development.

\section{References}

AHARI Z. (2001), Esfahan school of urban development, linguistics of elements and urban spaces, vocabulary and grammar (In Persian), Tehran University of Art, Tehran.

AHARI Z. (2005), Two religious institutions: a unit language, two expressions for comparing urban architectures of mosque and church in Esfahan school of urban development (In Persian), Journal of Golestan-e-Honar 2, 37-43.

AHARI Z. (2006), Esfahan school of urban development: grammar of urban foundation design (In Persian), Tehran University of Art, Tehran.

ATASH F., SHIRAZI BEHESHTIHA Y. S. (1998), New towns and their practical challenges: the experience of Poulad Shahr in Iran, Habitat International 22 (1), 1-13.

AZIZI M. M., ARBAB P. (2010), Identification and evaluation of the process of formation of identity in new towns. Case study: Hashtgerd new city (In Persian), Honar-Hy-Ye- Ziba 42, 47-58.

CASAKIN H., HERNÁNDEZ B., RUIZ C. (2015), Place attachment and place identity in Israeli cities: The influence of city size, Cities 42, Part B, 224-230.

FOROUTAN M. (2009), An analysis on urban spaces from Patriarch Tabriz to Safavid Isfahan (In Persian), Hoviatshahr 3 (4), 95-106.

FERDOWSIAN F. (2002), Modern and traditional urban design concepts and principles in Iran, PhD Thesis, University of Stuttgart, Stuttgart.

GHASEMZADEH B. (2013), Cultural spaces and urban identity (Integrating modern state of the art in cultural spaces), International Journal of Architecture and Urban Development $3(1), 57-62$.

HABIBI S. M. (1995a), School of Isfahan, enhancing and promoting the concept of government (In Persian), Proceedings of the $1^{\text {st }}$ Congress of Architectural and Urban Development History, Cultural Heritage Organization of Iran, Tehran.

HABIBI S. M. (1995b), Isfahan school of urban development (In Persian), Honar-Hy-YeZiba 3, 48-53.

HABIBI S. M. (2012), From Iranian cities to city: a historical analysis of city conception and its physical sight, thought and impact (In Persian), Tehran University Press, Tehran.

HABIBI S. M., HABIBI R. (2010), Imagination forms of Isfahan urban development school in miniatures (In Persian), Journal of Golestan-e-Honar 14, 5-17.

HABIB F., NADERI S. M., FOROUZANGOHAR H. (2008), Subdominant question in the conversation of city and identity (In Persian), Hoviatshahr 2 (3), 13-23.

KARIMIAN H. (2010), Cultural symbols in urban landscapes: between meaning, identity sense and spiritual calmness (In Persian), Journal of Human Geographical Researches 74, 119-132.

LYNCH K. (1960), The image of the city, The MIT Press, Cambridge.

MADANIPOUR A. (1996), Design of urban space: an inquiry into a socio-spatial process, Wiley, New York.

CHESHMEHZANGI A. (2015), Urban identity as a global phenomenon: hybridity and contextualization of urban identities in the social environment, Journal of Human Behavior in the Social Environment 25 (5), 391-406.

MOSHIRI S. R., RAJABI A., JAFARNEJAD S., FEZZEH S. (2011), The position of public areas in the creation of identity in new cities. Case study: Parand new city (In Persian), Sarzamin 8 (30), 1-17.

MOJTAHEDZADEH G. H. (2003), Urban planning in Iran (In Persian), Payam-E-Nour 
University Press, Tehran.

MAHDAVI M. (2010), School of Isfahan in urban development (In Persian), Journal of Mahe-Ketab 36, 80-91.

NAGHIZADEH M. (2013), City identity: principles, components and sights (In Persian), Jihad University Press, Tehran.

NEGARESTANI F., TEIMOURI M., ATASHINBAR M. (2010), Perspective theory: an approach to the continuation of identity in the process of urban renewal (In Persian), Bagh-eNazar 7 (14), 59-68.

OKTAY D. (2002), The quest for urban identity in the changing context of the city, Cities 19 (4), 261-271.

PATTON C. V., SAWICKI D. S. (1986), Basic methods of policy analysis and planning, Prentice-Hall, Englewood Cliffs, NJ.

Relph E. (1976), Place and Placelessness, Pion, London.

REZVANI A. R. (2005), Searching for urban identity of Mashhad (In Persian), Ministry of Housing and Urban Development Press, Tehran.

TEO S. E. (1996), Character and identity in Singapore new towns: planner and resident perspectives, Habitat International 20 (2), 279-294.

ZAMANI B., AREFI M. (2013), Iranian new towns and their urban management issues: a critical review of influential actors and factors, Cities 30, 105-112.

ZALI N., HATAMZADEH S., AZADEH S. R., SALMANI T. E. (2013), Evaluation of new towns construction in the around of Tehran megacity, Journal of Urban \& Environmental Engineering 7 (1), 15-23.

ZEBARDAST E. (2005), Do plans matter? Managing a metropolis with two directives for more than a decade: The case of Tehran City, Proceedings of the International Conference for Integrating Urban Knowledge and Practice, Gothenburg. $412-422$.

ZIARI K. (2006), The planning and functioning of new towns in Iran, Cities 23 (6),

Initial submission: 26.09.2014

Revised submission: 19.05.2015

Final acceptance: 17.06 .2015

Correspondence: Science and Research Branch, Islamic Azad University, Hesarak, Tehran, Iran

E-mail: behnam.ghasemzadeh@yahoo.com 
